\title{
USE OF MUNICIPAL SOLID WASTE INCINERATION BOTTOM ASH FOR THE REMOVAL OF HYDROGEN SULPHIDE $\left(\mathrm{H}_{2} \mathrm{~S}\right)$
}

\author{
NICOLAS TURGEON ${ }^{1}$, YANN LE BIHAN ${ }^{1}$, SYLVAIN SAVARD $^{1}$, MYLÈNE D'AOUST $^{2}$, \\ MATHIEU FOURNIER ${ }^{2} \&$ DAVID SÉNÉCHAL ${ }^{2}$ \\ ${ }^{1}$ Centre de Recherche Industrielle du Québec (CRIQ), Canada \\ ${ }^{2}$ Ville de Québec, Canada
}

\begin{abstract}
Hydrogen sulphide $\left(\mathrm{H}_{2} \mathrm{~S}\right)$ is a common malodorous gas causing many problems of odour and industrial atmospheric emissions potentially harmful to health. Québec City has mandated the Centre de Recherche Industrielle du Québec to determine the capacity of the bottom ash (BA) produced by its municipal solid waste (MSW) incinerator for the elimination of $\mathrm{H}_{2} \mathrm{~S}$. Tests carried out under controlled conditions (laboratory prototype consisting of three reactors containing respectively 10,20 and $30 \mathrm{~cm}$ BA beds) over a total period of $1750 \mathrm{~h}$ ( $\sim 73$ days) established that the elimination capacity of demetalized bottom ash produce by the Québec City MSW incinerator varies between $77 \pm 13$ and $121 \pm 20 \mathrm{~g} \mathrm{H}_{2} \mathrm{~S} / \mathrm{kg}$ dry BA. These results are considerably higher than those published by other authors and demonstrate the potential of this material for various industrial applications (i.e. treatment of landfill gas, pretreatment of biogas produced by anaerobic digestion, etc.) in accordance with the principles of industrial ecology.

Keywords: hydrogen sulfide, incineration, municipal solid waste, bottom ash, industrial ecology.
\end{abstract}

\section{INTRODUCTION}

Controlling hydrogen sulfide $\left(\mathrm{H}_{2} \mathrm{~S}\right)$ emissions (toxic and smelling of rotten eggs) remains a key environmental issue for many industrial sectors (landfill sites, rendering, composting, wastewater treatment, biomethanization, pulp and paper, petrochemicals, agri-food, ranching, etc.) [1]. The main technologies that are currently available for the treatment of $\mathrm{H}_{2} \mathrm{~S}$ rely on absorption (chemical washing), adsorption (activated charcoal) or biological processes (biofiltration, bacterial bed, bioscrubber). Although the effectiveness of these so-called conventional technologies has been largely demonstrated in industrial contexts over the years [2], their main disadvantage generally lies in the cost of operation (chemical products, adsorbents, packing, etc.) which may become very significant, if not prohibitive, given the volume to be treated. In fact, this is what has prompted several R\&D teams to identify and test different approaches of treatment based on the principle of industrial ecology. That is to say the identification of innovative and sustainable outlets for the use and recovery of industrial residues [3], [4].

The Québec City municipal solid waste MSW incinerator has a capacity of 312,000 t/year, and receives waste from the residential, institutional, commercial and industrial sectors from the entire Greater Québec City Area and from various neighbouring regional county municipalities (RCMs). Sludge from the two wastewater treatment stations is also dehydrated, dried and incinerated. The incineration of waste and sludge produces approximately 70,000 t/year of grate ash, also known as bottom ash (BA). Once it has been demetalized, approximately 58,000 t/year of bottom ash are sent to the Québec City landfill site (LEVQ, St-Joachim sector). A portion is used for the day-to-day recovery of waste, while the rest goes into the landfill. In order to increase the rate of recovery of residual materials and the useful life of the LEVQ, Québec City's Waste Management Division aims to re-use the bottom ash produced by its incinerator. To this end, its focus is on the positive features 
of bottom ash, including odour control, improved bearing capacity and hydraulic conductivity. Previous studies have shown that due to its physico-chemical characteristics, bottom ash has some interesting properties for the treatment of gases such as $\mathrm{CO}_{2}, \mathrm{H}_{2} \mathrm{~S}$, etc. [5]-[18]. The objective of this project was to determine, using controlled testing in laboratory, the actual capacity of the bottom ash produced by the Québec City MSW incinerator for the elimination of gaseous $\mathrm{H}_{2} \mathrm{~S}$.

\section{MATERIALS AND METHODS}

\subsection{The experimental pilot}

Tests were conducted in the Centre de Recherche Industrielle du Québec's (CRIQ) laboratories under controlled conditions. The experimental pilot (Fig. 1) essentially consists of a synthetic gas generation system $\left(\mathrm{N}_{2} / \mathrm{H}_{2} \mathrm{~S}\right.$ blend), three reactors named $\mathrm{R} 1, \mathrm{R} 2$ and $\mathrm{R} 3$ (10 cm diameter columns) and an analytical system for the continuous monitoring of $\mathrm{H}_{2} \mathrm{~S}$. The reactors R1, R2 and R3 contain different levels of bottom ash (BA beds $=10,20$ and $30 \mathrm{~cm}$ respectively) representative of their conventional use at the site as a daily cover to minimise adverse amenity impacts such as odour, dust, litter, the presence of scavengers and vermin, and the risk of fire. All of the other parameters remained identical for each of the reactors (initial $\mathrm{H}_{2} \mathrm{~S}$ concentration, superficial speed, gas temperature, water content and density of the BA beds, etc.).

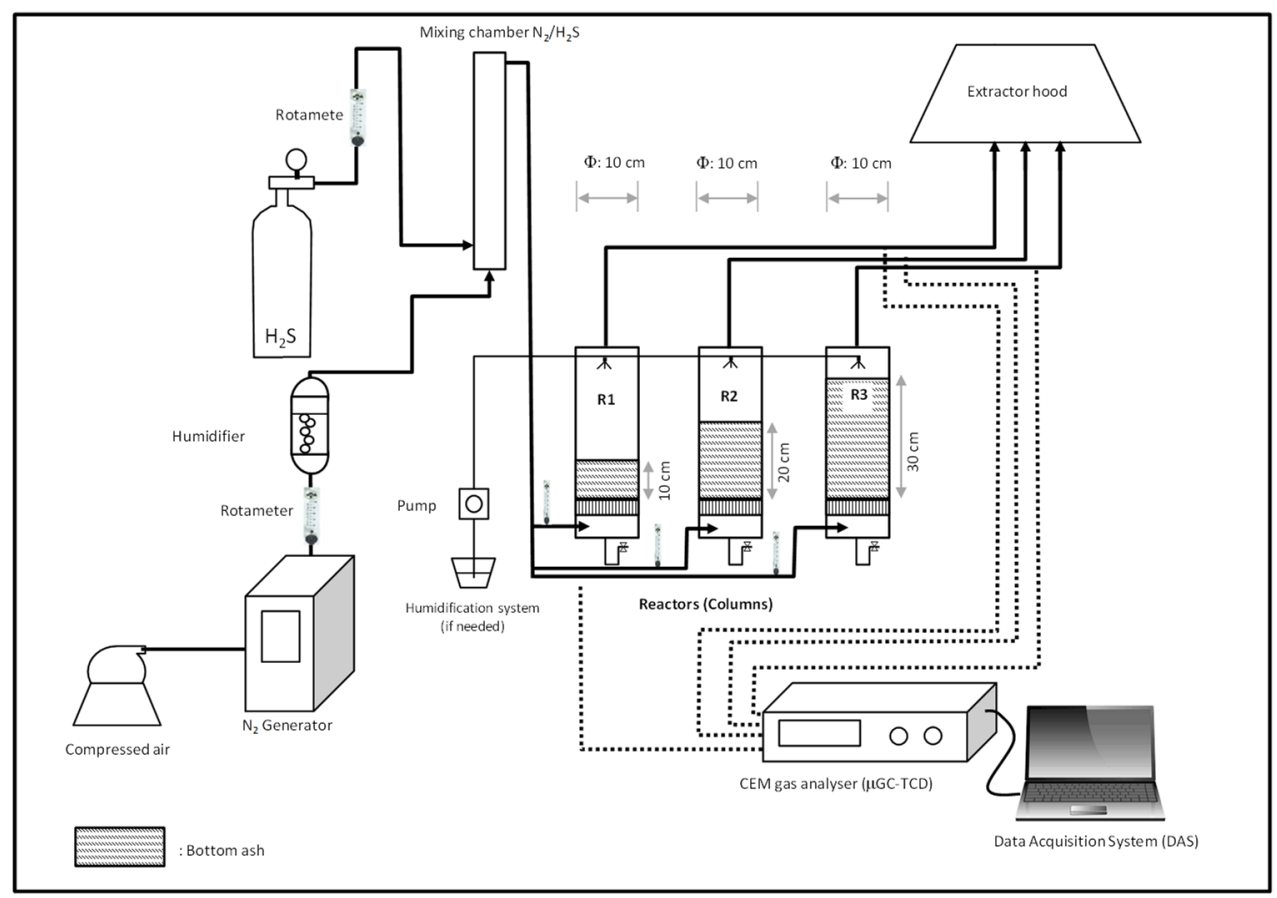

Figure 1: Experimental set-up. 


\subsection{The bottom ash (BA) used}

The fresh BA used for these tests was collected directly at the LEVQ - St-Joachim sector from the truck in provenance of the demetalization plant. This sample was kept at $4^{\circ} \mathrm{C}$ in hermetically sealed plastic containers (20 litres) until the testing began.

Table 1 shows the BA mass that was added for each reactor. The BA beds were compacted to the desired height using successive small $10 \mathrm{~cm}$ layers. The bulk density of the BA packing in the three (3) reactors [mass of BA (wet $\mathrm{kg}$ ) / volume of BA bed $\left(\mathrm{m}^{3}\right)$ ] varies between 1400 and $1570 \mathrm{~kg} / \mathrm{m}^{3}$.

\subsection{The synthetic gas}

The synthetic gas used for the laboratory testing consists of a mix of hydrogen sulfur $\left(\mathrm{H}_{2} \mathrm{~S}\right)$ in concentrations varying from approximately $100 \mathrm{ppmv}\left(139 \mathrm{mg} / \mathrm{m}^{3}\right)$ to $2775 \mathrm{ppmv}$ $\left(\sim 3850 \mathrm{mg} / \mathrm{m}^{3}\right)$ with a balance of gaseous nitrogen $\left(\mathrm{N}_{2}\right)$. The gas $\left(\mathrm{N}_{2}\right)$ that is generated is humidified ahead of time in a column filled with water (bubbler). The $\mathrm{H}_{2} \mathrm{~S}$ is then injected using a pure gas cylinder and adjusted with the help of a microrotameter until the desired concentration is reached. The operating conditions for the three (3) reactors are described in Table 2 . The gas flow was set at $2 \mathrm{~L} / \mathrm{min}$ (calibrated rotometers) for all reactors and all over the experiment period. The gas concentration was increased during the experiment (100 ppmv, $1000 \mathrm{ppmv}$ and $2000 \mathrm{ppmv}$ ) in order to accelerate the $\mathrm{H}_{2} \mathrm{~S}$ saturation of the bottom ash in the reactors. The calculated gas contact time is 7, 14 and 21 seconds for R1, $\mathrm{R} 2$ and $\mathrm{R} 3$, respectively.

Table 1: Description of the reactors.

\begin{tabular}{ccccc}
\hline \multirow{2}{*}{ Reactor } & $\begin{array}{c}\text { Height of BA bed } \\
(\mathbf{c m})\end{array}$ & \multicolumn{2}{c}{ Mass of BA Added } & Bulk Density of BA \\
\cline { 2 - 5 } & 10 & $($ wet $\mathbf{~ k g})$ & $(\mathbf{d r y} \mathbf{~ k g})$ & $\mathbf{( k g / \mathbf { m } ^ { \mathbf { 3 } } )}$ \\
\hline $\mathrm{R} 1$ & 20 & 2.1 & 0.9 & 1400 \\
\hline $\mathrm{R} 2$ & 30 & 3.7 & 1.8 & 1400 \\
\hline $\mathrm{R} 3$ & & & 3.0 & 1570 \\
\hline
\end{tabular}

Table 2: Reactor operating conditions.

\begin{tabular}{lcccc}
\multicolumn{1}{c}{ Parameter } & R1 & R2 & R3 \\
\hline Diameter $(\mathrm{cm})$ & 10 & 10 & 10 \\
\hline BA bed height $(\mathrm{cm})$ & $-1-650 \mathrm{h:}$ & $100 \mathrm{ppmv}\left(139 \mathrm{mg} / \mathrm{m}^{3}\right)$ & 30 \\
\hline & $-650-1465 \mathrm{~h}:$ & $1000 \mathrm{ppmv}\left(1390 \mathrm{mg} / \mathrm{m}^{3}\right)$ & \\
Inlet $\mathrm{H}_{2} \mathrm{~S}$ concentration & $-1465-1750 \mathrm{h:}$ & $2000 \mathrm{ppmv}\left(2780 \mathrm{mg} / \mathrm{m}^{3}\right)$ & \\
& & 2 & 2 & 2 \\
\hline Gas flow $(\mathrm{L} / \mathrm{min})$ & 7 & 14 & 21 \\
\hline Contact time ${ }^{1}$ (seconds) & & 10 & 20 \\
\hline
\end{tabular}

${ }^{1}$ Considering that the porosity of the BA bed is $30 \%$ according to Ducom et al. [6]. 


\subsection{Conditioning of the BA}

The literature reports a non-negligible sequestration of $\mathrm{CO}_{2}$ in the $\mathrm{BA}$ [11]. Before starting the tests, the BA beds were conditioned ahead of time in the reactors using a mix of $\mathrm{CO}_{2} / \mathrm{N}_{2}$ $(50 \% \mathrm{v} / \mathrm{v} / 50 \% \mathrm{v} / \mathrm{v})$ gas to saturation. That conditioning over approximately $48 \mathrm{~h}$ aimed to ensure that the maturation of the BA, a chemical reaction of the bottom ash with atmospheric $\mathrm{CO}_{2}$ (i.e. the hardening of a material also called "superficial induration") was completed before evaluating its capacity to eliminate $\mathrm{H}_{2} \mathrm{~S}$.

\subsection{Analytical monitoring}

$\mathrm{H}_{2} \mathrm{~S}$ concentrations at entry and exit from the reactors were continuously monitored using an Agilent $/ 490$ brand $\mu$ GC-TCD gas analyzer with an extended detection range (from $10 \mathrm{ppm}$ to $100 \% \mathrm{v} / \mathrm{v}$ ) and equipped with an automated multi-port sampling system. The frequency of analysis was set to hourly for each sample collection point. The bottom ash characterization was done in a laboratory specializing in inorganic chemistry (COREM, Québec, Canada).

\section{RESULTS AND DISCUSSION}

The total duration of the testing was $1750 \mathrm{~h}$ ( $\sim 73$ days) between November 17, 2015 and February 15, 2016.

\subsection{Characterization of the pre-test bottom ash}

Table 3 shows the main results of the characterization of the bottom ash sample used in this study. The comparison with other studies revealed certain similarities in regard to the elementary composition of the BA (metal oxides analyzed by X-ray fluorescence). However, significant differences concerning the concentration of organic carbon (analyzed by LECO combustion/capsule and infra-red detector) were noted. The bottom ash used by Radu-Tirnoveanu et al. [5] contained approximately four (4) times more organic carbon compared to the BA sample used for this project. The efficiency of combustion (municipal solid waste incinerators) could account for that result. The initial water content of the BA sample used for the tests was approximately $21 \%$.

\subsection{Results}

Fig. 2 shows the removal efficiency (RE) of $\mathrm{H}_{2} \mathrm{~S}$ over time for each reactor. The RE was calculated based on the concentration of $\mathrm{H}_{2} \mathrm{~S}$ at the reactor inlet and outlet according to eqn (1), as follows:

$$
\mathrm{RE} \mathrm{H}_{2} \mathrm{~S}(\%)=\frac{[\mathrm{H} 2 \mathrm{~S}]_{\text {inlet }}-[\mathrm{H} 2 \mathrm{~S}]_{\text {outlet }}}{[\mathrm{H} 2 \mathrm{~S}]_{\text {inlet }}} \times 100 \%,
$$

where: $\quad$ RE $\mathrm{H}_{2} \mathrm{~S}=$ Removal efficiency of $\mathrm{H}_{2} \mathrm{~S}(\%)$

$\left[\mathrm{H}_{2} \mathrm{~S}\right]_{\text {inlet }}=$ Inlet concentration of $\mathrm{H}_{2} \mathrm{~S}(\mathrm{ppm})$

$\left[\mathrm{H}_{2} \mathrm{~S}\right]_{\text {outlet }}=$ Outlet concentration of $\mathrm{H}_{2} \mathrm{~S}(\mathrm{ppm})$

The removal efficiency, initially $100 \%$, decreases gradually after approximately $400 \mathrm{~h}$ (17 days) to approximately $30 \%$ at the end of the testing (after 70 days) for R 1 containing 10 cm of BA (Fig. 2(a)). The removal efficiency of R2 $(20 \mathrm{~cm}$ of BA) starts to decrease gradually after approximately $900 \mathrm{~h}$ (37 days) to approximately $60 \%$ at the end of the testing (Fig. 2(b)). For R3 (30 cm of BA), the removal efficiency starts to decrease gradually after 
Table 3: Characterization of the fresh bottom ash (Québec City).

\begin{tabular}{|c|c|c|c|c|}
\hline & Parameter & $\begin{array}{l}\text { Unit } \\
\text { (dry basis) }\end{array}$ & $\begin{array}{l}\text { Bottom ash } \\
\text { Québec } \\
\text { City }\end{array}$ & $\begin{array}{l}\text { Bottom ash } \\
\text { Analyzed by Radu-Tirnoveanu et al. [5] }\end{array}$ \\
\hline \multirow{25}{*}{$\begin{array}{l}\frac{\tilde{d}}{0} \\
\frac{0}{0} \\
\frac{\pi}{\pi} \\
\frac{0}{2}\end{array}$} & $\mathrm{SiO}_{2}$ & $\%(w / w)$ & 44.9 & 42.3 \\
\hline & $\mathrm{Al}_{2} \mathrm{O}_{3}$ & $\%(\mathrm{w} / \mathrm{w})$ & 11.3 & 7.5 \\
\hline & $\mathrm{Fe}_{2} \mathrm{O}_{3}$ & $\%(w / w)$ & 12.3 & 7.6 \\
\hline & $\mathrm{MgO}$ & $\%(\mathrm{w} / \mathrm{w})$ & 1.94 & 2.6 \\
\hline & $\mathrm{CaO}$ & $\%(w / w)$ & 13.8 & 16.3 \\
\hline & $\mathrm{Na}_{2} \mathrm{O}$ & $\%(w / w)$ & 4.16 & 6 \\
\hline & $\mathrm{K}_{2} \mathrm{O}$ & $\%(w / w)$ & 1.78 & 1.1 \\
\hline & $\mathrm{TiO}_{2}$ & $\%(w / w)$ & 1.01 & 0.6 \\
\hline & $\mathrm{MnO}$ & $\%(w / w)$ & 0.17 & $\mathrm{n} / \mathrm{a}$ \\
\hline & $\mathrm{P}_{2} \mathrm{O}_{5}$ & $\%(w / w)$ & 1.75 & 1.2 \\
\hline & $\mathrm{Cr}_{2} \mathrm{O}_{3}$ & $\%(w / w)$ & 0.05 & $\mathrm{n} / \mathrm{a}$ \\
\hline & $\mathrm{V}_{2} \mathrm{O}_{5}$ & $\%(\mathrm{w} / \mathrm{w})$ & $<0.01$ & $\mathrm{n} / \mathrm{a}$ \\
\hline & $\mathrm{ZrO}_{2}$ & $\%(\mathrm{w} / \mathrm{w})$ & 0.03 & $\mathrm{n} / \mathrm{a}$ \\
\hline & $\mathrm{ZnO}$ & $\%(w / w)$ & 0.51 & $\mathrm{n} / \mathrm{a}$ \\
\hline & PAF & $\%(\mathrm{w} / \mathrm{w})$ & 6.4 & $\mathrm{n} / \mathrm{a}$ \\
\hline & S Total & $\%(w / w)$ & 0.52 & 0.3 \\
\hline & $\mathrm{Cl}$ & $\%(w / w)$ & 0.4 & 0.4 \\
\hline & $\mathrm{C}$ organic & $\%(w / w)$ & 0.26 & 1.1 \\
\hline & $\mathrm{C}$ inorganic & $\%(w / w)$ & 0.62 & 1 \\
\hline & $\mathrm{pH}$ & $(-)$ & 11.7 & $\mathrm{n} / \mathrm{a}$ \\
\hline & Bulk Density & $\mathrm{kg} / \mathrm{m}^{3}$ (wet basis) & 1181 & $\mathrm{n} / \mathrm{a}$ \\
\hline & Water content & $\%(\mathrm{w} / \mathrm{w}$, wet basis $)$ & 21.1 & $\sim 15 \%$ \\
\hline & Total organic matter & $\%(\mathrm{w} / \mathrm{w})$ & 4.8 & $\mathrm{n} / \mathrm{a}$ \\
\hline & Ashes & $\%(w / w)$ & 95.2 & $\mathrm{n} / \mathrm{a}$ \\
\hline & Acid neutralization capacity & $(\%) \mathrm{CaCO}_{3} \mathrm{eq}$ & 28.43 & $\mathrm{n} / \mathrm{a}$ \\
\hline
\end{tabular}

approximately $1300 \mathrm{~h}$ (54 days) to approximately $90 \%$ at the end of the testing (Fig. 2(c)). Given that the operating conditions (gas flow rate, concentration of $\mathrm{H}_{2} \mathrm{~S}$, etc.) remained identical for all of the reactors, this result indicates that the saturation rate at the end of the tests is $\mathrm{R} 1>\mathrm{R} 2>\mathrm{R} 3$.

The change in the mass of $\mathrm{H}_{2} \mathrm{~S}$ resulting from the bottom ash packing for $\mathrm{R} 1$ is presented in Fig. 3(a). The theoretical maximum mass calculated based on the acid neutralizing capacity (ANC) of the bottom ash (BNQ 0419-090 method) for this reactor is $87.5 \mathrm{~g} \mathrm{of}_{2} \mathrm{~S}$. The total cumulated mass of $\mathrm{H}_{2} \mathrm{~S}$ in $\mathrm{R} 1$ exceeds the theoretical maximum mass to reach $109.4 \mathrm{~g}$ of $\mathrm{H}_{2} \mathrm{~S}$ at the end of the tests. That result confirms that the elimination of $\mathrm{H}_{2} \mathrm{~S}$ in these materials is a complex process (adsorption, formation of salt from the metal oxides that are present, etc.) and are not linked only to chemical neutralization. The change in $\mathrm{H}_{2} \mathrm{~S}$ mass resulting from the bottom ash packing for R2 is presented in Fig. 3(b). The theoretical maximum mass calculated based on the ANC of the bottom ash for this reactor is $175.0 \mathrm{~g}$ of $\mathrm{H}_{2} \mathrm{~S}$. The total cumulated mass of $\mathrm{H}_{2} \mathrm{~S}$ in $\mathrm{R} 2$ exceeds the theoretical maximum mass to reach $195.9 \mathrm{~g}$ of $\mathrm{H}_{2} \mathrm{~S}$ at the end of the tests. The change in $\mathrm{H}_{2} \mathrm{~S}$ mass resulting from the bottom ash packing for R3 is presented in Fig. 3(c). This one shows that the BA bed in R3 is less saturated because the total cumulated mass of $\mathrm{H}_{2} \mathrm{~S}$ at the end of the tests $\left(232.2 \mathrm{~g}\right.$ of $\left.\mathrm{H}_{2} \mathrm{~S}\right)$ is less than the theoretical maximum mass calculated based on the $\mathrm{ANC}$ of the bottom ash for this reactor (290.4 $\mathrm{g}$ of $\mathrm{H}_{2} \mathrm{~S}$ ). 


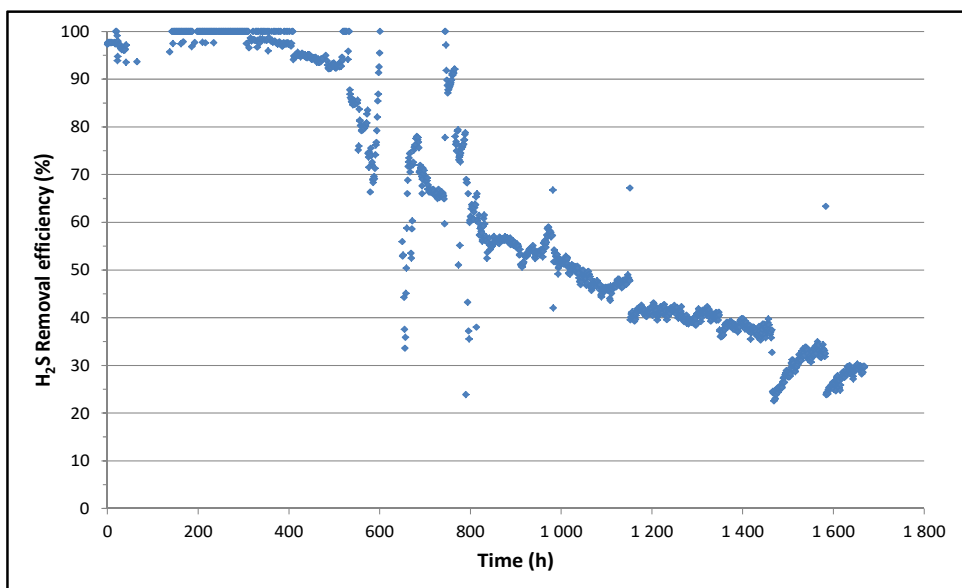

(a)

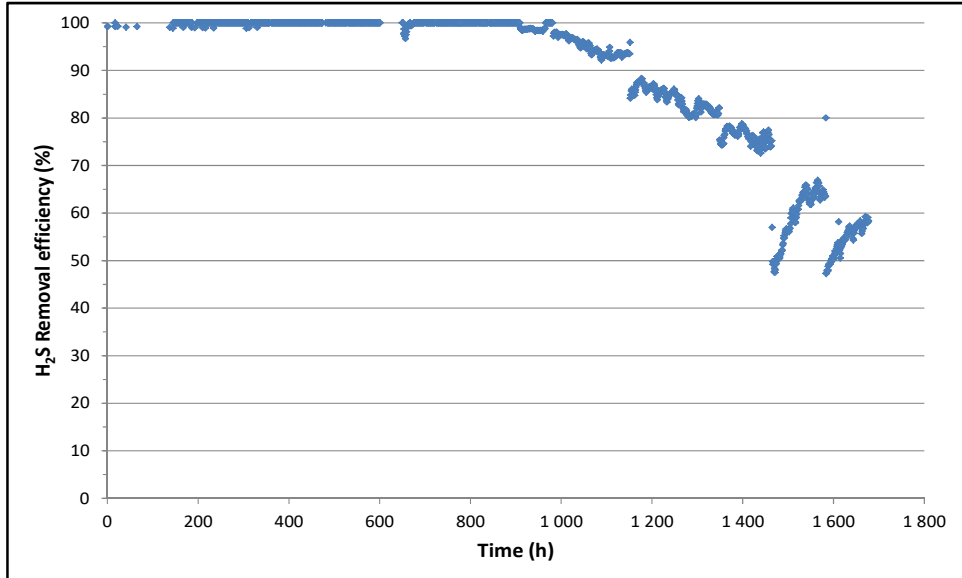

(b)

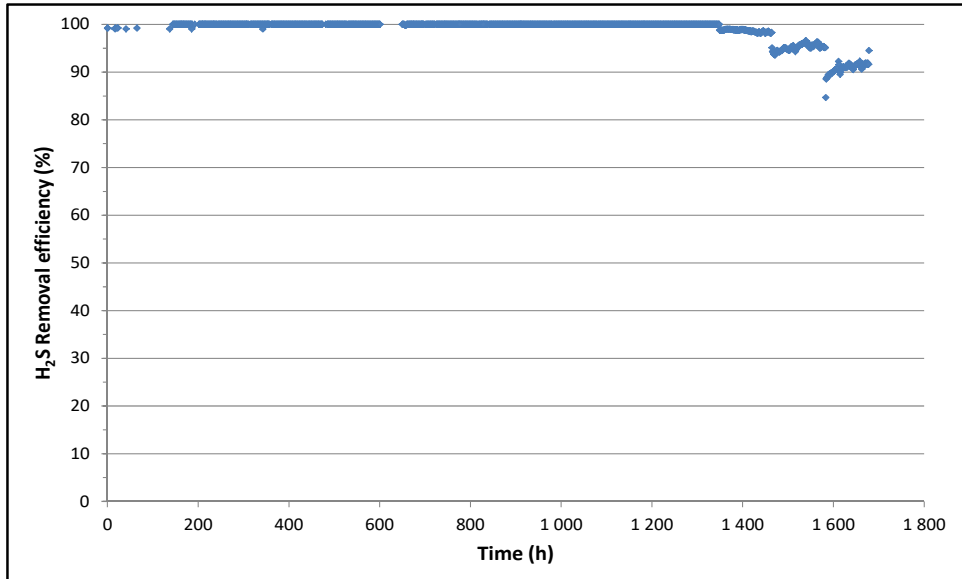

(c)

Figure 2: Change in the removal efficiency of $\mathrm{H}_{2} \mathrm{~S}$ over time: (a) R1; (b) R2; (c) R3. 


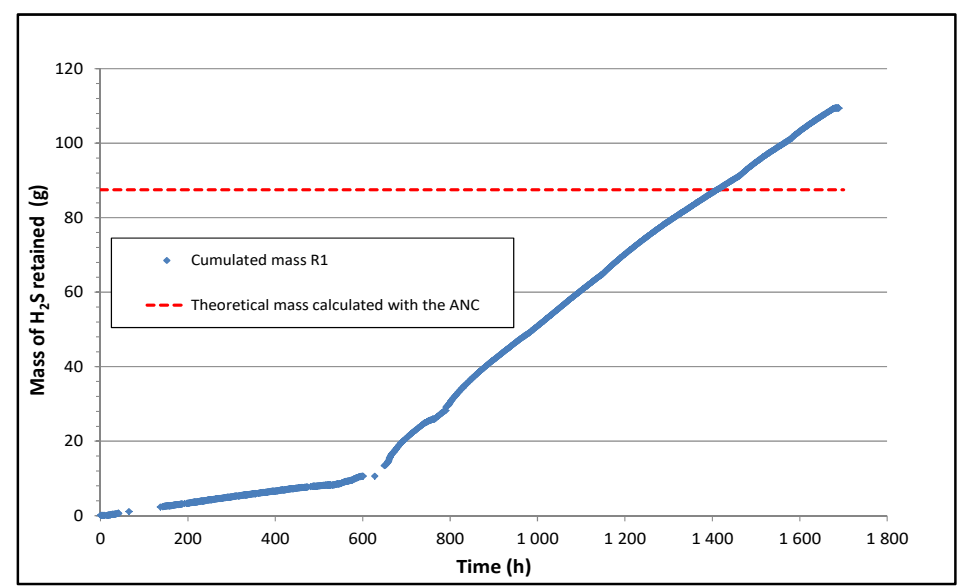

(a)

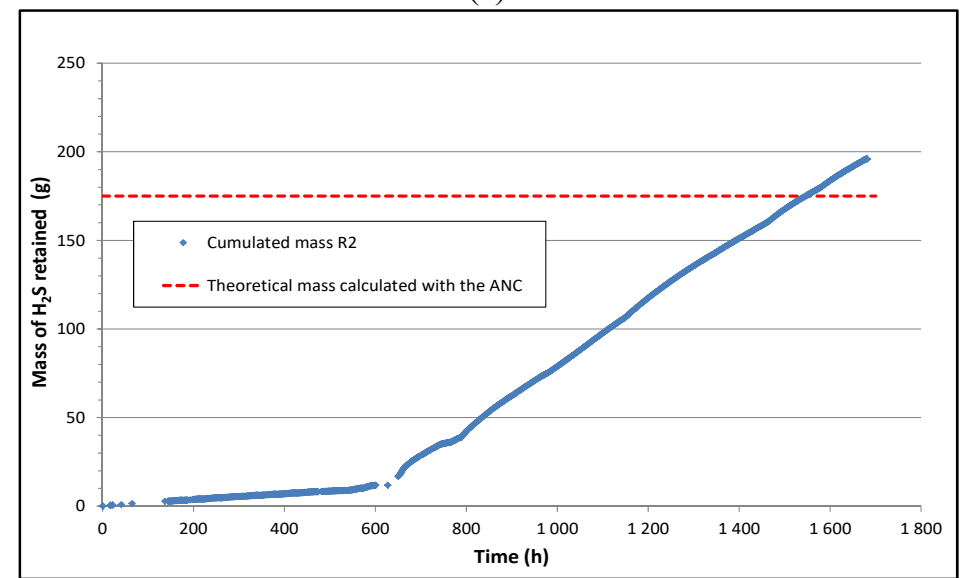

(b)

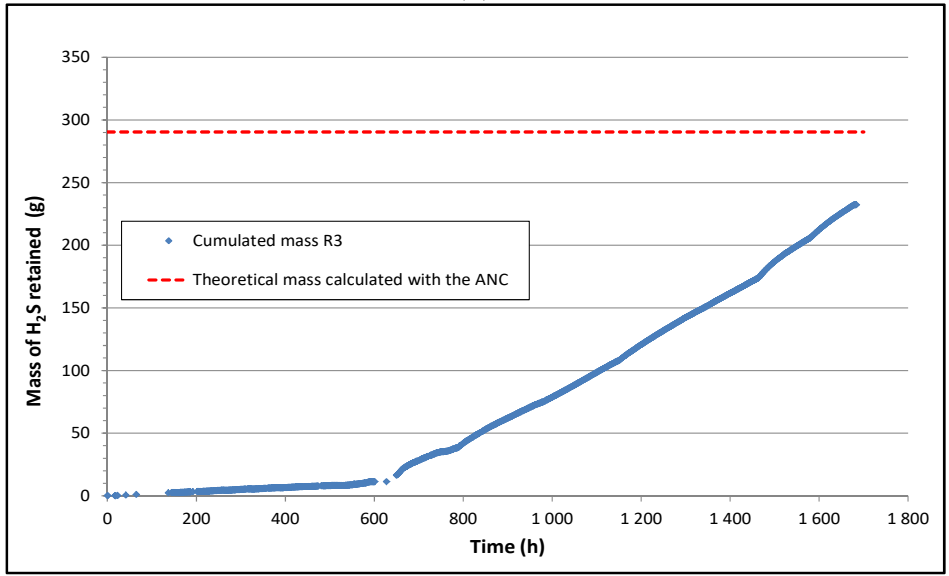

(c)

Figure 3: Change in the cumulated mass of $\mathrm{H}_{2} \mathrm{~S}$ in the BA reactors: (a) R1; (b) R2; (c) R3. 


\subsection{Determination of the Elimination Capacity (EC)}

The Elimination Capacity (EC) expressed as the relation between the mass of $\mathrm{H}_{2} \mathrm{~S}$ removed and the total amount of packed dry BA $\left(\mathrm{g} \mathrm{H}_{2} \mathrm{~S} / \mathrm{kg}\right.$ dry BA) was calculated according to eqn (2):

$$
\mathrm{EC}\left(\mathrm{g} \mathrm{H}_{2} \mathrm{~S} / \mathrm{kg} \text { dry BA }\right)=\frac{\sum_{t=0}^{t}[(C i-C o) t \times \Delta t \times(F) t]}{M_{B A}} \times \frac{1 \mathrm{~g}}{1000 \mathrm{mg}} \times \frac{1 \mathrm{~m}^{3}}{1000 l},
$$

where $C i$ is the inlet $\mathrm{H}_{2} \mathrm{~S}$ concentration $\left(\mathrm{mg} / \mathrm{m}^{3}\right)$, Co is the outlet $\mathrm{H}_{2} \mathrm{~S}$ concentration $\left(\mathrm{mg} / \mathrm{m}^{3}\right)$, $t$ is the time ( $\mathrm{min}), F$ is the gas flow rate $(1 / \mathrm{min})$ and $M_{B A}$ is the mass of dry BA in the reactor $(\mathrm{kg})$.

Fig. 4 shows the cumulated mass of $\mathrm{H}_{2} \mathrm{~S}$ eliminated $\left(\mathrm{g} \mathrm{H}_{2} \mathrm{~S} / \mathrm{kg}\right.$ dry BA) based on the cumulated mass of $\mathrm{H}_{2} \mathrm{~S}$ at inlet $\left(\mathrm{g} \mathrm{H}_{2} \mathrm{~S} / \mathrm{kg}\right.$ dry BA) for each reactor. The EC for reactors $\mathrm{R} 1$, $\mathrm{R} 2$ and $\mathrm{R} 3$ is, respectively, $121 \pm 20,108 \pm 18$ and $77 \pm 13 \mathrm{~g} \mathrm{H}_{2} \mathrm{~S} / \mathrm{kg}$ dry BA. These results indicate a higher removal capacity of Québec City's bottom ash than for the results published by Radu-Tirnoveanu et al. [5]: $3 \mathrm{~g}$ of $\mathrm{H}_{2} \mathrm{~S} / \mathrm{kg}$ dry BA and Fontsere Obis et al. [7]: $56 \mathrm{~g}$ of $\mathrm{H}_{2} \mathrm{~S} / \mathrm{kg}$ dry BA under similar conditions. This figure also reveals that the three (3) reactors were not fully saturated when the tests were stopped, and still had some $\mathrm{H}_{2} \mathrm{~S}$ retention capacity (non-flat slope) at the end of the testing.

\subsection{Characterization of the packing (BA)}

Table 4 summarizes the characteristics of the BA packing when the reactors are dismantled after the testing. There is an increase in the total sulfur content compared to the fresh BA $(0.52 \%)$. The water content of the packing is relatively low (between 3.1 and $3.4 \%$ ) compared to the fresh BA, whose initial water content was in the order of $21 \%$. This shows that the gas humidification at the inlet to the reactors was not optimal. Nonetheless, the humidity in the BA beds appears to have been sufficient to promote the physico-chemical elimination of $\mathrm{H}_{2} \mathrm{~S}$. A reduction in $\mathrm{pH}$ was also observed for the three reactors, dropping from 11.7 for the fresh bottom ash to 8.6 for R1, 8.0 for R2 and 8.5 for R3.

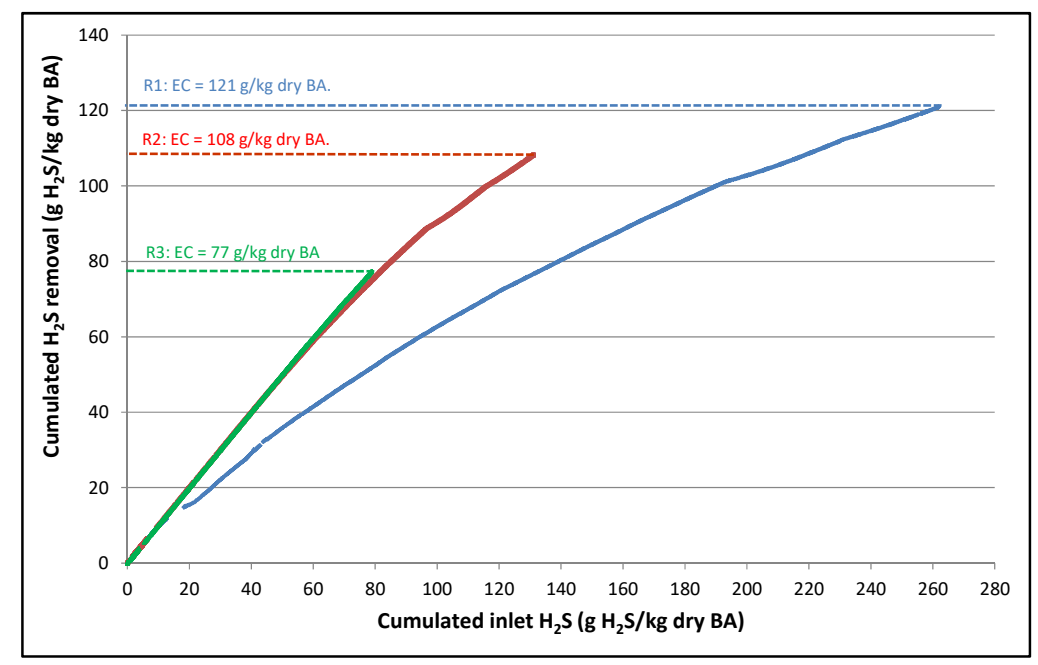

Figure 4: Cumulated $\mathrm{H}_{2} \mathrm{~S}$ removal in function of cumulated inlet $\mathrm{H}_{2} \mathrm{~S}$. 
Table 4: Characterization of the BA packing used in the reactors.

\begin{tabular}{lccccl}
\hline \multicolumn{1}{c}{ Parameter } & Unit & R1 & R2 & R3 & \multicolumn{1}{c}{ Method } \\
\hline S total & $\%(w / w)$ & 8.33 & 8.47 & 6.49 & COREM B-41 \\
\hline C organic & $\%(w / w)$ & 0.2 & 0.24 & 0.23 & COREM B-58 \\
\hline C mineral & $\%(w / w)$ & 1.1 & 0.99 & 0.89 & COREM B11 \\
\hline $\mathrm{pH}$ & $(-)$ & 8.6 & 8.0 & 8.5 & CRIQ MA4018 \\
\hline Water content & $(\%)$ & 3.13 & 3.42 & 3.25 & CRIQ MA4089 \\
\hline Total organic matter & $(\%)$ & 10.4 & 10 & 8.37 & BNQ 0413-200/2005 \\
\hline Ashes & $(\%)$ & 89.6 & 90 & 91.63 & BNQ 0413-200/2005 \\
\hline
\end{tabular}

\subsection{Mass balance}

Table 5 shows the results of the calculations for the mass balance for each reactor in regard to sulfur. For example, the total mass of sulfur potentially captured by the R1 bottom ash represents $103 \mathrm{~g}(223.1 \mathrm{~g}-120.1 \mathrm{~g})$. The total mass of captured sulfur calculated out of S total in this reactor indicates a value of $70.7 \mathrm{~g} \mathrm{~S}[(8.33 \%-0.52 \%) / 100 \times 0.9053$ dry $\mathrm{kg} \times 1000]$. This leaves a shortfall of $32.3 \mathrm{~g}$ to complete the balance in this column (that is to say $32.3 / 223.1 \times 100 \%=14 \%$ ). For R2 and R3, the indeterminate forms equal $18 \%$. The shortfalls for the mass balances can be attributed to flow variations and to the precision of the measuring instruments.

\section{CONCLUSION}

The results obtained in this study demonstrate the potential of bottom ash (BA) produce by the Québec City MSW incinerator for eliminating hydrogen sulfide $\left(\mathrm{H}_{2} \mathrm{~S}\right)$. The tests were run during 73 days under controlled conditions (laboratory prototype) with a synthetic gas $\left(\mathrm{H}_{2} \mathrm{~S}\right.$ mix: $100 \mathrm{ppmv}-2775 \mathrm{ppmv}, \mathrm{N}_{2}$ balance). The three reactors containing different

Table 5: Mass balance (S).

\begin{tabular}{|c|c|c|c|c|c|c|}
\hline \multirow{2}{*}{ Description } & \multicolumn{2}{|c|}{ R1 } & \multicolumn{2}{|c|}{$\mathbf{R 2}$} & \multicolumn{2}{|c|}{$\mathbf{R 3}$} \\
\hline & g S & $\%$ & g S & $\%$ & g S & $\%$ \\
\hline (1) Mass of S- $\mathrm{H}_{2} \mathrm{~S}$ introduced into the reactor & 223.1 & 100 & 223.4 & 100 & 223.0 & 100 \\
\hline (2) Mass of S- $\mathrm{H}_{2} \mathrm{~S}$ at the outlet of the reactor & 120.1 & 54 & 39.0 & 17 & 4.4 & 2 \\
\hline (3) Total mass of S captured on BA bed (1)-(2) & 103.0 & - & 184.4 & - & 218.6 & - \\
\hline $\begin{array}{l}\text { (4) Total mass of S captured on BA bed (S total } \\
\text { laboratory analysis) }\end{array}$ & 70.7 & 32 & 143.9 & 64 & 179.3 & 80 \\
\hline (5) Indeterminate forms (3)-(4)) & 32.3 & 14 & 40.4 & 18 & 39.3 & 18 \\
\hline
\end{tabular}


bottom ash packing beds $(\mathrm{R} 1=10 \mathrm{~cm} ; \mathrm{R} 2=20 \mathrm{~cm} ; \mathrm{R} 3=30 \mathrm{~cm})$ show elimination capacities $\mathrm{EC}$ of $121 \pm 20,108 \pm 18$ and $77 \pm 13 \mathrm{~g} \mathrm{H}_{2} \mathrm{~S} / \mathrm{kg}$ dry BA, respectively. These results are significantly higher than those reported in the literature under similar conditions [5], [7]. The analysis of the acid neutralizing capacity applied directly to the fresh BA sample shows a theoretical removal capacity of $96.7 \mathrm{~g}$ of $\mathrm{H}_{2} \mathrm{~S} / \mathrm{kg}$ dry BA. The total mass of sulfur captured in the BA of R1 validates a minimal removal capacity of approximately $83 \mathrm{~g}^{\circ} \mathrm{H}_{2} \mathrm{~S} / \mathrm{kg}$ dry BA. This study confirms that the use of bottom ash to control $\mathrm{H}_{2} \mathrm{~S}$ emissions can represent recovering opportunities such as daily covers on landfill sites (odour management) or the pre-treatment of biogas (production of biomethane).

\section{REFERENCES}

[1] ADEME, Pollution olfactive Origines-Législation-Analyse-Traitement, Agence de l'environnement et de la maîtrise de l'énergie, Dunod, Paris, 2005.

[2] Davis, W.T., Air Pollution Engineering Manual, 2nd ed., AWMA, Wiley Interscience, 2000.

[3] Starr, K., Gabarrell, X. \& Villalba G., Life cycle assessment of biogas upgrading technologies. Waste Management, 32, pp. 991-999, 2012.

[4] Sarperi, L., Surbrenat, A., Kerihuel, A. \& Chazarenc, F., The use of an industrial by-product as a sorbent to remove $\mathrm{CO}_{2}$ and $\mathrm{H}_{2} \mathrm{~S}$ from biogas. Journal of Environmental Chemical Engineering, 2(2), pp. 1207-1213, 2014.

[5] Radu-Tirnoveanu, D., Ducom, G., Benadda, B, Germain, P. \& Pascual, C., Interactions biogaz / mâchefers d'incinération d'ordures ménagères - Rétention d' $\mathrm{H}_{2} \mathrm{~S}$. Déchets Revue Francophone d'Écologie Industrielle, 39, pp. 25-31, 2005.

[6] Ducom, G., Radu-Tirnoveanu, D., Benadda, B., Germain, P. \& Pascual, C., Biogas Municipal solid waste incinerator bottom ash interactions: Sulphur compounds removal. Journal of Hazardous Materials, 166, pp. 1102-1108, 2009.

[7] Fontsere Obis, M., Germain, P., Troesch. O., Spillemaecker. M. \& Benbelkacem, H, Use of MSWI bottom ash for biogas desulfurization. Proceedings Sardinia 2015, Fifteenth International Waste Management and Landfill Symposium, Cagliari, Italy, 5-9 October 2015, CISA Publisher, 2015.

[8] Mostbauer, P., Lenz, S. \& Lechner, P., Upgrading of lean landfill gas using MSWI bottom ash. Proceedings of the $11^{\text {th }}$ International Waste Management and Landfill Symposium, Cagliari, Italy, pp. 1-6, 2007.

[9] Mostbauer, P., Lenz, S. \& Lechner, P., MSWI bottom ash for upgrading of biogas and landfill gas. Environmental Technology, 29(7), pp. 757-764, 2008.

[10] Mostbauer, P., Olivieri, T., Lombardi, L. \& Paradisi, A., Pilot-scale upgrading of landfill gas and sequestration of $\mathrm{CO}_{2}$ by MSWI bottom ash. Ash 2012 Conference, January, pp. 25-27, 2012.

[11] Mostbauer, P., Lombardi, L., Olivieri, T. \& Lenz, S., Pilot scale evaluation of the BABIU process - Upgrading of landfill gas or biogas with the use of MSWI bottom ash. Waste Management, 34(1), pp. 125-133, 2014.

[12] Mostbauer, P., Knapp, A., Müller, W., Insam, H., Tertsch, S., Fernández-Delgado, M. \& Bockreis, A., Removal of hydrogen sulphide from biogas - Results of the Neustift pilot plant. Proceedings Sardinia 2015, Fifteenth International Waste Management and Landfill Symposium, Cagliari, Italy, 5-9 October 2015, CISA Publisher, 2015.

[13] Chavez, R.H. \& Guadarrama, J.J., Biogas treatment by ashes from incineration processes. Clean Techn Environ Policy, 17, pp. 1291-1300, 2015. 
[14] Del Valle-Zermeño, R., Romero-Güiza, M.S., Chimenos, J.M. \& Formosa, J., Biogaz upgrading using MSWI bottom ash: An integrated municipal solid waste management. Renewable Energy, 80, pp. 184-189, 2015.

[15] Hrobak, D., Attenuation of hydrogen sulfide from landfill gas study and exploration of construction and demolition debris characteristics and production, Thesis, University of New Hampshire, USA, 140 pp., 2009.

[16] Lin, C.Y., Hesu, P.H. \& Yang, D.H., Removal of hydrogen sulfide gas and landfill leachate treatment using coal bottom ash. Journal of the Air \& Waste Management Association, 51(6), pp. 939-945, 2001.

[17] Miao, C., Modelling of landfill gas adsorption with bottom ash for utilization of renewable energy, Thesis, Universität Duisburg-Essen, Fakultät für Ingenieurwissenschaften, Bauwissenschaften, Bauingenieurwesen, 2011.

[18] Sadatgol, S., Upgrading of landfill gas with household waste slag. Master of Science Thesis in Chemical Engineering for Energy and Environment, Royal Institute of Technology, Stockholm, Sweden, 2013. 